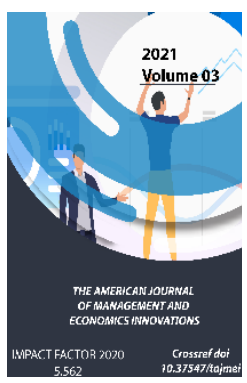

\title{
Opportunities For The Development Of Ecotourism In Bukhara Region
}

\author{
Aziz Anvarovich Kodirov \\ Independent Researcher, Bukhara State University, Uzbekistan
}

Journal Website:

http://theamericanjour

nals.com/index.php/taj

mei

Copyright: Original

content from this work

may be used under the

terms of the creative

commons attributes

4.0 licence.

\section{ABSTRACT}

The article describes the importance of ecotourism, which is considered one of the most developed types of Tourism. Specific features and directions of the development of ecotourism in the region are highlighted. The tourist potential of Bukhara region as well as opportunities for the development of ecotourism has been studied. Also, priority directions of development of ecotourism in the region are indicated.

\section{KEYWORDS}

Innovative economy, tourism, region, ecological tourism, potential, tourist potential, Bukhara region, agro-tourism, infrastructure,

cluster.

\section{INTRODUCTION}

The importance of innovation and the use of digital technologies in the economy are growing in the current conditions; tourism is one of the sectors that make a significant income to the national economy in the countries of the world and further development of tourism in the world economy.

"Around the world, in countries at all development levels, many millions of jobs and businesses are dependent on a strong and thriving tourism sector" said Zurab Pololikashvili, Secretary General of the World Tourism Organization (UNWTO). Tourism has also been a driving force in protecting natural and cultural heritage, preserving them for future generations to enjoy" (www.unwto.org). 
Currently, the World Tourism Organization recognizes adventure tourism, sea and water tourism and ecotourism as the most promising areas of Tourism. Among these types of tourism, one of the young and promising areas is ecotourism, which is characterized by its development and seriousness. According to the UN World Tourism Organization, ecotourism is currently one of the five main strategic areas of Tourism Development.

\section{THE MAIN FINDINGS AND RESULTS}

The unique beautiful nature of Uzbekistan, its unique landscape, its diverse unique flora and fauna, its archaeological finds with a rare, world-class nature, its pole-ontological remains, Geological cross sections that are rare on Earth, hundreds of natural monuments create the ground for the development of this type of Tourism. In this regard, serious attention is paid to the development of ecotourism in Uzbekistan in recent years.

In the appeal of the president of the Republic of Uzbekistan Shavkat Mirziyoev to the Oliy Majlis "there is a great potential for the development of tourism in the unique nature of our country, national reserves, and mountainous regions. In particular, the development of medical tourism, pilgrimage tourism and ecotourism not only gives a great impetus to the economy, but also to the development of social spheres [1] is also a vivid proof of our above views.

The world-famous and well-known cities of our country, such as Bukhara, Samarkand and Khiva, make a special contribution to the development of tourism, which is considered a strategic network of the economy.
Bukhara is one of the ancient cities of Central Asia and is one of the largest and most famous shopping centers on the Great Silk Road. The city gained fame all over the world with its rich and unique history, formed over thousands of years, which is closely connected with the most important stages of the development of universal civilization, and with its huge contribution to the development of cultural, educational and spiritual and religious values.

During the period of independent development, like the entire tourism network of Uzbekistan, the city of Bukhara and the Bukhara region are in the center of the state's constant attention to promoting the tourist potential, forming modern infrastructure of tourism, creating favorable conditions for tourists. Today, the number of subjects of tourist activity employed in the development of the tourism industry and its associated infrastructure in Bukhara region is increasing rapidly [6].

In the Islamic world, it was used to add a Sharif, that is, a sacred suffix to Buhari's name. It should be noted that the city of Bukhara was declared the capital of Islamic world culture in 2020 by the Islamic Organization for Education, Science and culture.

The Bukhara region has an overwhelming potential in terms of Tourism. The fact that 660 objects of material cultural heritage are registered in the region means a lot. Decree of the president of the Republic of Uzbekistan "On measures for the rapid development of the tourist potential of the city of Bukhara and the Bukhara region in 2017-2019" May 19, 2017, as well as "On measures for the development 
of the tourism sector in 2018-2019" August 16, 2017, was an important step towards realization of these opportunities. In accordance with these decisions, a number of works have been carried out to create favorable conditions for foreign tourists visiting the region and tourists of our country, to further improve the quality of service rendered to them.

In order to consistently develop the tourism sector, further improve the tourism industry and infrastructure in the region, a number of new venues, cultural and entertainment venues have been created on the basis of the program approved by the President. The holy shrines in the region - Khoja Abdulkhaliq Gijduvani, Khoja Arif ar-Revgari, Khoja Mahmud Anjir Fagnavi, Khoja Ali Romitani, Khoja Muhammad Babayi Samosi, Sayyid Amir Kulol, Khoja Bahouddin Naqshband and Chorbakr are undergoing large-scale construction and repair works.

At the same time, the demand for infrastructure facilities, including hotels, restaurants, vehicles, quality roads, entertainment parks, sanitary and hygienic canals, motels and potential personnel and qualified companion translators is increasing in the region. In the program approved by the Cabinet of Ministers of the Republic of Uzbekistan dated September 21, 2019 № 794 "On measures for socio-economic development of the Bukhara region in 20192023" for 2019-2023 years, the Cabinet of Ministers of the Republic of Uzbekistan approved the measures for the socioeconomic development of the Bukhara region from Paris, Madrid, Turkey, additional information about the airport shuttle and "hotel - Bus flights along the route "seven pir pilgrims"; repair of roads leading to" seven pir (pir - a wise man) "pilgrims; achieving further attraction of tourists to this object with the involvement of international organizations (UNESCO) and local experts on restoration, conservation and reconstruction of the city' ancient Poykent" and development of new tourist destinations such as Eco and agrotourism are envisaged.

In recent years, we can observe the growth of tourism potential of Bukhara region in the field of ecotourism.

Currently, the region has lakes "Jayron", "Zikri” and "Khadicha”, "Qaraqir”, "Ogitma”, “Jilvon Jilosi”, "Bukhara Hunting”, "Shifo Nur Koz"), gastronomic tourism (National cuisine) sweets), Agrotourism (Romitan, Bukhara, Gijduvan, Vobkent districts) Rural tourism (craftsmen, guest houses), Cultural tourism (theatrical performances), tasting center of JSC “Bukhara Shohrud", miniature center "Usta Davron", Beach (Lower- tomb, Tudakol) and other types of tourist routes and services.

A new eco-Agro tourism route has been established in the land area of "Vardonze Irismet" LLC in the Shafirkon District of the region, which includes horse and camel rides, hunting tourism, gastronomic tourism services and archaeological potential of the region. In the Romitan district, a tour of the ancient monument "Bufrontepa", a tour of horses and camels, hunting tourism services and accommodation in the country, restaurant and beach zones are organized; The fact that the ALAT district is treated with sand and sunlight, cooking food from natural cocaine and meat of healing animals, hunting of moth milk, fish and wild animals, hiking in horses and camels, living in the country, services of 
restaurants and beach zones is an important ground for the development of ecotourism.

Also in the Shofirkon District of the region, in the "Afzal Polimer Zamin" there are sportshealth, hunting fish with wild animals, treatment with natural herbs, services of horse and camel rides, master classes in cooking in the village of Ushot (a profession that is engaged in almost $70 \%$ of the population of the village) in the village of Ushot in the neighborhood of; showing the processes of obtaining honey and conducting master classes in obtaining honey with the participation of tourists, hunting tourism in forest hunting in the Citizens' Assembly of Kovacha mahalla of Karakul district, ownership of the zoo and ecotourism potential is evidence of increasing opportunities for the development of ecotourism in the region.

We can see that the development of ecotourism also has a positive impact on the socio-economic development of the region. Only in 2019, a total of 3 projects were implemented on the account of the development of the ecotourism sector in Bukhara region with a total value of 33.5 billion soums (own funds 32.0 billion soums, bank loans 1.5 billion soums) and 90 new jobs were created.

- On the territory of the Kirillishon mahalla of Olot District, LLC “Shifo Nur Ko'z" was established the center of ecotourism and health for 2018-2019 years, where services are provided for tourists to organize tours, gastronomic tourism, rest in the country, treatment in the sand and sun, tincture from various medicinal herbs.

- The object of ecotourism was established in April 2019 near Lake "Zikri" of karavulbazar district. On the territory of Ekomarkaz there is a hotel, a restaurant, and services for tourists such as beach zones, excursions in horses and camels, fishing and hunting of wild animals are organized.

“Jilvon Jilosi" eco-agro-tourism center was established in July 2019 by "Afzal Polimer Zamin" LLC of Shafirkan district. The center provides gastronomic, sports, fishing, travel and tourism services. There are 200,000 trees, 1,000 species of animals (horses, camels, ostriches, turkeys, rabbits, etc.).

"Oasis Safari \& Spa" Ecotourism Center has been established by Safari Vogue LLC near the ancient "Borontepa" monument in Romitan district. The "Oasis Safari \& Spa" Ecotourism Center has a national and modern style restaurant, cottages, lemonade stand, beach area, gastronomic, safari, quad biking and camel rides, fish and wildlife hunting.

In 2020, "Bukhara Hunting" LLC plans to establish a hunting and ecotourism center in the Karakir watershed of Peshko district at a total cost of 3 billion soums; hunting, gastronomic, tour tourism and boat trips in the lake area and recreation in the beach areas are organized here.

So, our studies show that the tourist potential of Bukhara region, including its eco-touristic potential, has been growing sharply in recent years. The development of ecotourism as a new direction of tourism is one of the strategic tasks of Tourism Development in the region, and this direction is considered as a promising type of tourism, which will create an important basis for the development of 
ecotourism in the region in the future.

We can observe that the negative impact of the pandemic crisis in 2020 on the world tourism sector has not bypassed the development of ecotourism in the region.

\section{CONCLUSION}

In this regard, in our opinion, for the development of ecotourism in the region, it is desirable to carry out:

- Based on the basic elements and criteria that make up ecotourism, inventory of the ecotourism of the region and identification of new eco-touristic objects;

- Implementation of a system of effective use of Public-Private Partnership and Cluster methods for the development of ecotourism;

- Development of concrete measures to improve infrastructure in remote areas of the region in order to further increase the eco-touristic potential;

In order to increase the effectiveness of the system of attracting tourists to ecotourism, develop "3D maps" that provide full information about the ecotourism potential of the region and place them on Google and other search engines of the global Internet and develop mobile applications that provide information about ecotourism sites.

\section{REFERENCES}

1. Address of the President of the Republic of Uzbekistan Shavkat Mirziyoev to the Oliy Majlis 29.12.2018.

2. Decree of the President of the Republic of Uzbekistan dated February 7, 2017 No PD-4947 "On the Action Strategy for further development of the Republic of Uzbekistan". https://lex.uz/docs/-3107036

3. Muminov Azizbek Ziyoviddinovich, Ecological tourism is an important factor of development http://dx.doi.org/10.26739/2181-9599-20193-35.

4. Xamidov O.X. Improving the mechanism of ecotourism management - an important area of strategic development of the tourism industry. Scientific electronic journal "International Finance and Accounting”. №2, April, 2017.

5. Khaitboev R. (2018) Ecological tourism. Study guide. - Tashkent: - p. 248.

6. https://lex.uz/docs/-3577062.

7. www.unwto.org. 